ROCZNIK ADMINISTRACJI PUBLICZNEJ 2020 (6)

ARTYKUŁY / ARTICLES

Prawo i administracja w wymiarze europejskim i międzynarodowym

Law and administration in their European and international dimension

Klaudia Baran ${ }^{1}$, Wiktoria Burek², Martyna Gibek ${ }^{3}$

\title{
Wpływ Covid-19 na społeczeństwo i prawo. Wybrane aspekty polskich i europejskich regulacji prawnych
}

\section{Wstęp}

Wybrane aspekty polskich i europejskich regulacji prawnychPrzedmiotem badań jest negatywny wpływ wirusa SARS-CoV-2 na wybrane aspekty społeczne i prawne w poszczególnych państwach Unii Europejskiej. Dlaczego jest to temat ważny? Przede wszystkim dotyka każdego $\mathrm{z}$ nas bezpośrednio: zamknięte szkoły, uczelnie wyższe, galerie handlowe, miejsca kultury, ograniczony dostęp do sklepów, odwołane wydarzenia kulturalne, zawieszone linie lotnicze i zamknięte granice ${ }^{4}$. Gdzieś pomiędzy troską o zdrowie swoje i innych a obserwacją medialnych doniesień pojawiają się kolejne pytania, przede wszystkim o funkcjonowanie gospodarki i kształt obowiązującego prawa. Wydawać by się mogło, że temat pandemii jest tematem zamkniętym - nic bardziej mylnego. Ograniczenia są znoszone i przywracane. Sytuacja, którą przedstawiono $\mathrm{w}$ artykule tyczy się momentu wprowadzenia największych restrykcji w państwach Unii Europejskiej, to jest od początku marca bieżącego roku do czerwca bieżącego roku, kiedy to wirus zaskoczył społeczeństwo oraz przedstawicieli władzy państwowej.

Celem artykułu jest ukazanie negatywnego wpływu wirusa COVID-19 na społeczeństwo i prawo. Obostrzenia wprowadzane w Polsce, jak i w Europie cechuje istotny wpływ na społeczeństwo. Co więcej, zaistniała sytuacja

1 Klaudia Baran, Instytut Prawa i Ekonomii, Uniwersytet Pedagogiczny im. Komisji Edukacji Narodowej w Krakowie

2 Wiktoria Burek, Instytut Prawa i Ekonomii, Uniwersytet Pedagogiczny im. Komisji Edukacji Narodowej w Krakowie

3 Martyna Gibek, Instytut Prawa i Ekonomii, Uniwersytet Pedagogiczny im. Komisji Edukacji Narodowej w Krakowie

4 Koronawirus $w$ Polsce. Rząd zamyka szkoły, kina i teatry, https://www.tuwroclaw.com/wiadomosci,koronawirus-w-polsce-rzad-zamyka-szkoly-kina-i-teatry,wia5-3266-53841.html, (17.03.2020). 
stała się także dużym wyzwaniem dla ustawodawcy, powodując konieczność podjęcia odpowiedzialnych decyzji, skutecznych w zakresie ochrony zdrowia i życia obywateli. Pojawił się problem wynikający z konfliktu wartości, granicą pomiędzy wolnością a dobrem ogółu. Jakie ograniczenia praw i wolności można wprowadzać aby były one zgodne z podstawowymi zasadami, wartościami i prawami człowieka? Co nakazać, czego zakazać i jak zapobiec bezrobociu na większą skalę, a także jaki kształt nadać nowemu prawu, które będzie regulować te kwestie, tak aby z jednej strony było skuteczne a z drugiej realizowało podstawowe zasady, prawa i wolności człowieka.

Artykuł ma na celu przedstawienie obostrzeń wprowadzonych przez władze państw Unii Europejskiej a także ich praktycznego wpływu na sytuację społeczną. Innymi słowy, pokazanie, jak prawo tworzone w okresie pandemii wpłynęło na społeczeństwo, a także do jakich paradoksów doprowadziły wprowadzone obostrzenia. Warto zaznaczyć, że analizie został poddany tylko pewien odcinek czasu okresu pandemii COVID-19, w którym restrykcje były najsurowsze, tj. od czasu wprowadzenia stanu epidemii do okresu „łagodzenia obostrzeń”.

\section{Prawa człowieka a zdrowie - uwagi ogólne}

Istotnym niebezpieczeństwem wynikającym z wpływu ,wirusa z Wuhan” na społeczeństwo jest zagrożenie poszanowania praw człowieka. Przede wszystkim dotyczy to prawa do zdrowia, które obejmuje między innymi prawo dostępu do służby zdrowia, do informacji, zakaz dyskryminacji w świadczeniu usług medycznych czy wolność od dokonywanych bez zgody osób zainteresowanych interwencji lekarskich. Pandemia niesie ze sobą również zagrożenia dla innych praw człowieka, takich jak: wolności od arbitralnego zatrzymania, swobody podróżowania, wolności słowa, praw gospodarczych i społecznych. Prawa te - co typowe dla praw człowieka - mają charakter względny, można je jednak ograniczać tylko wtedy, gdy nakładane obostrzenia spełniają kryterium niezbędności, proporcjonalności i zgodności z prawem.

Analiza problematyki wirusa COVID-19 pod względem prawnym uwidacznia kolizję norm. $Z$ jednej strony występuje uzasadniona potrzeba i możliwość legalnego ograniczania praw człowieka z racji pandemii (brak obostrzeń przyczyniłby się do większej ilości zakażeń), z drugiej strony wprowadzone zmiany i restrykcje ograniczają podstawowe prawa człowieka. Sytuację w niektórych państwach ratuje wprowadzenie stanu wyjątkowego, który pozwala na ograniczanie praw i wolności obywatelskich. 


\section{Polskie regulacje prawne w związku z pandemią COVID-19}

Rozporządzeniem Ministra Zdrowia z dnia 20 marca 2020 roku $^{5}$ na obszarze Rzeczypospolitej Polskiej został wprowadzony do odwołania stan epidemii w związku z zakażeniami wirusem SARS-CoV-2. 31 marca 2020 roku wydane zostało rozporządzenie Rady Ministrów ${ }^{6}$ zwiększające obostrzenia względem obywateli. Zgodnie z rozporządzeniem, do 11 kwietnia bieżącego roku obowiązywał zakaz przemieszczania się, z wyjątkiem m.in. wykonywania czynności zawodowych lub zadań służbowych i zaspokajania niezbędnych potrzeb związanych z bieżącymi sprawami życia codziennego, w tym dostępu do opieki zdrowotnej oraz zakupu niezbędnych towarów. Przemieszczać się można było również w celu wykonywania ochotniczo i bez wynagrodzenia świadczeń na rzecz przeciwdziałania skutkom COVID-19, w tym w ramach wolontariatu a także w celu sprawowania lub uczestniczenia w sprawowaniu kultu religijnego. Liczbę osób, które jednocześnie mogły uczestniczyć w nabożeństwie mszy świętej lub innym obrzędzie religijnym ograniczono do pięciu, wyłączając osoby sprawujące posługę. Od 1 kwietnia 2020 roku nie tylko osoby, które powróciły do kraju zobowiązane były do poddania się obowiązkowej 14-dniowej kwarantannie, lecz również ich domownicy. Obostrzenie to godziło w wolność osobistą i spotkało się z jawną krytyką, ponieważ dotknęło osoby stale przebywające w kraju, które mogły nie mieć styczności z potencjalnym chorym, w tym wypadku przyjezdnym domownikiem. Prawo do wolności osobistej zostało ograniczone nie tylko wobec osoby przyjezdnej ale również rodziny, a to budzi pytania o niezbędność i proporcjonalność ograniczeń.

Inne restrykcje, które zostały wprowadzone to: zakaz wychodzenia $\mathrm{z}$ domu, nałożony na osoby niepełnoletnie (możliwość opuszczania domu jedynie pod opieką osoby dorosłej). Wprowadzony zakaz stanowił ograniczenie prawa do wolności oraz równości wobec prawa. Problem praktyczny pojawiał się wówczas, gdy osoba niepełnoletnia mieszkała pod opieką dziadków, którzy są w grupie ryzyka zakażenia wirusem. Nawet taka osoba, która niebawem osiągnęłaby pełnoletniość nie mogła samodzielnie opuścić zamieszkiwanego lokalu w celu zrobienia zakupów.

Wśród restrykcji wprowadzono również obostrzenia dotyczące ograniczenia możliwości korzystania z parków, bulwarów, plaż, promenad czy ograniczenia w korzystaniu z rowerów miejskich. Oprócz tych obostrzeń, które kolidują z głównym prawem człowieka, a mianowicie prawem do wolności osobistej, restrykcje dotykają swobody działalności gospodarczej

5 Rozporzadzenie Ministra Zdrowia $z$ dnia 20 marca 2020 roku w sprawie ogtoszenia na obszarze Rzeczypospolitej Polskiej stanu epidemii, Dz.U.2020. poz. 491.

6 Rozporzadzenie Rady Ministrów z 31 marca 2020 roku sprawie ustanowienia określonych ograniczeń, nakazów i zakazów w związku z wystąpieniem stanu epidemii, Dz.U. 2020 poz. 566. 
hotele i salony urody. Rozporządzenie ${ }^{7}$ przewidywało zamknięcie salonów piękności, tzn. salonów kosmetycznych czy fryzjerskich a także ograniczenie liczby prosperujących hoteli. Przepis ten spowodował istotne straty materialne dla pracowników i pracodawców prowadzących salony. Zamknięte zostały również muzea i ośrodki kultury, co spowodowało ograniczenie prawa do korzystania z dóbr kultury. Przedstawiona regulacja bezpośrednio godzi także w prawa człowieka II generacji, w szczególności w prawo do pracy oraz uczestnictwa w życiu kulturalnym. Ograniczono także liczbę osób, które jednocześnie mogą uczestniczyć w nabożeństwie mszy świętej lub innym obrzędzie religijnym, co może stanowić naruszenie prawa do wolności religijnej. W „najgorętszym okresie restrykcji” tylko 5 wiernych mogło brać udział w sprawowaniu kultu religijnego, z wyłączeniem kapłanów i osób sprawujących posługę.

$\mathrm{Z}$ dniem 16 kwietnia 2020 roku w całym kraju został wprowadzony nakaz zakrywania, przy pomocy odzieży lub jej części, maski albo maseczki, ust $i$ nosa $a^{8}$. Była to dość ogólna reguła zachowania, dotycząca noszenia specjalistycznych maseczek, zatem nie stanowiło złamania nakazu zakrywanie twarzy i ust różnego rodzaju odzieżą szalikami, chustami, itp.

Nakaz dotyczył osób przebywających w ogólnodostępnej przestrzeni publicznej: na drogach, placach, w zakładach pracy i w budynkach użyteczności publicznej, w obiektach i placówkach handlowych/usługowych, na targowiskach, na terenie wspólnych nieruchomości. Do zakrywania ust i nosa zobowiązane zostały również osoby, które poruszały się transportem zbiorowym oraz samochodami, jeżeli podróżowały nimi osoby wspólnie niezamieszkujące. Od obowiązku zakrywania ust i nosa wyłączone zostały niektóre grupy osób, m.in. osoby, które nie mogły zakrywać ust i nosa ze względu na swój stan zdrowia, dzieci poniżej 4. roku życia oraz duchowni sprawujący kult religijny. $Z$ jednej strony polskie rozwiązania prawne na tle europejskich nie są niczym nowym (podobną restrykcję wprowadził Kanclerz Austrii Sebastian Kurz ${ }^{9}$ ), z drugiej jednak strony nakaz koliduje z prawami i wolnościami człowieka pomimo tego, że został wprowadzony w trosce o życie i zdrowie obywateli. Problem pojawia się również w przypadku konsekwencji prawnych za naruszenie obostrzeń, bądź niezastosowanie się do ww. nakazu. Sankcje za złamanie nakazu zakrywania ust i nosa w ogólnodostępnej przestrzeni publicznej w Polsce mają charakter represji finansowych i sięgają nawet kilkunastu tysięcy złotych, a co za tym idzie są nieproporcjonalne w stosunku do innych kar za czyny niedozwolone.

7 Ibidem.

8 Rozporzadzenie Rady Ministrów z dnia 15 kwietnia 2020 r. zmieniajace rozporządzenie $w$ sprawie ustanowienia określonych ograniczeń, nakazów $i$ zakazów w związku z wystapieniem stanu epidemii, Dz. U. 2020 poz. 673.

9 Bundesgesetzblatt für die Republik Österreich - COVID - 19 Gesetz, NR: GP XXVII IA 483/A AB 120 S. 27. BR: 10293 AB 10300 S. 906. 
Wprowadzone zakazy i nakazy ograniczyły trzy ważne wolności obywateli: wolność osobistą (art. 30 Konstytucji $\mathrm{RP}^{10}$ ), wolność poruszania się po terytorium Rzeczypospolitej (art. 52 Konstytucji RP) oraz wolność sumienia i wyznania (art. 53 Konstytucji RP). Wprowadzone regulacje w istotny sposób ograniczyły podstawowe prawa człowieka. Sytuacja epidemiologiczna i towarzyszące jej rozwiązania prawne ograniczyły w Polsce prawo do zgromadzeń, prawo do ochrony własności, a także prawo do rozwoju, co znacząco zdestabilizowało przemysł i gospodarkę.

\section{Sankcje za nieprzestrzeganie prawa}

Wysokie sankcje finansowe w okresie epidemii COVID-19 za złamanie przepisów w trybie administracyjnym na bazie specustawy ${ }^{11}$ spotkały się z dezaprobatą społeczną. Grożą one za naruszenie zasad kwarantanny, obowiązku hospitalizacji lub izolacji w związku z COVID-19, a także przemieszczania się wbrew zakazom wydanym na podstawie specustawy i powołanego rozporządzenia. Osoba naruszająca zakaz przemieszczania się rowerem mogła zostać obciążona karą administracyjną w wysokości nawet 30 tysięcy złotych ${ }^{12}$. Zgodnie z literą prawa, kara nakładana jest przez Inspektora Sanitarnego w trybie administracyjnym, i pobierana z konta w ciągu 7 dni od dnia wydania decyzji ${ }^{13}$. O tym, czy sprawa trafi do Sanepidu, decydowała na ogół Policja. Na podstawie wniosku Policji Inspektor Sanitarny wydaje decyzję administracyjną. Od decyzji przysługuje odwołanie w terminie do $14 \mathrm{dni}^{14}$.

Według Rzecznika Praw Obywatelskich (RPO): Co prawda specustawa koronawirusowa zatrzymała bieg terminów, ale w tym wypadku zwlekanie nie ma sensu. Im wcześniej złoży się odwołanie, tym wcześniej będzie się nim mógł zająć organ II instancji. Odwołanie wnosi się do organu wyższego stopnia za pośrednictwem organu, który wydał decyzję. Jeśli decyzję wydał państwowy powiatowy inspektor sanitarny, druga instancja jest państwowy wojewódzki inspektor sanitarny. Jeżeli decyzje wydał w I instancji wojewódzki inspektor, to organem II instancji jest główny inspektor sanitarny ${ }^{15}$.

10 Konstytucja Rzeczypospolitej Polskiej z dnia 2 kwietnia 1997 r., Dz.U. Nr 78, poz. 483 ze zm.

11 Ustawa z dnia 31 marca 2020 r. o zmianie niektórych ustaw w zakresie systemu ochrony zdrowia zwiazanych $z$ zapobieganiem, przeciwdziałaniem $i$ zwalczaniem COVID-19, Dz. U. 2020 poz. 567.

12 Kolejne kroki $w$ walce $z$ koronawirusem $w$ sklepie mniej osób, ograniczenia w poruszaniu nieletnich, a parki, plaże i bulwary zamknięte, https://www.gov.pl/ web/koronawirus/kolejne-kroki, (13.07.2020).

13 Kara 30000 czy mandat 500?, https://www.rpo.gov.pl/pl/content/koronawirus-kara-administracyjna-sanepid-mandat-policja-faq-od.\%2C-23, (13.07.2020).

14 Ibidem.

15 Kara $30000 \mathrm{zł} \mathrm{czy} \mathrm{mandat} 500$ zł? Od czego to zależy? Informator RPO, https://www.rpo.gov.pl/sites/default/files/Kara\%20administracyjna\%20czy\%20mandat\%20-\%20informator\%20RPO.pdf, (13.07.2020). 
Wielu prawników zgłasza także poważne zastrzeżenia co do zgodności z Konstytucją Rzeczypospolitej Polskiej ustanowienia prawa do nakładania tak wysokich kar wymierzanych $\mathrm{w}$ drodze postępowania administracyjnego bez wezwania osobistego, skoro nie został ogłoszony stan nadzwyczajny. Utrzymanie decyzji w mocy przez organ odwoławczy, a także przeprowadzenie skutecznej egzekucji kary pieniężnej występuje stosunkowo często. Pozostaje zawsze prawo do sądu. Termin na złożenie skargi do wojewódzkiego sądu administracyjnego od decyzji ostatecznej organu II instancji wynosi $30 \mathrm{dni}^{16}$. Co prawda w stanie epidemii termin jest wstrzymany - warto go jednak przestrzegać, a skargę należy złożyć w możliwie najkrótszym czasie.

W przypadku otrzymania mandatu od Policji, oscylującego w granicach 500 złotych zgodnie z kodeksem wykroczen ${ }^{17}$, postępowanie wyglądało nieco inaczej. Mandaty - jak wynika z analiz RPO - najczęściej pojawiały się w przypadku złamania zakazu poruszania się wydanego przez Radę Ministrów w rozporządzeniu z 31 marca $2020 \mathrm{roku}^{18}$. Rozporządzenie (częściowo już zmienione) nie było precyzyjne ${ }^{19}$. Zabraniało przemieszczenia się w ogóle, z zastrzeżeniem pięciu wyjątków: zaspokajania potrzeb życiowych, pracy, pomocy wolontaryjnej, praktyk religijnych i zadań wynikających z prawa łowieckiego ${ }^{20}$. Do Biura RPO wpływały skargi, w których opisywano sytuację zatrzymań za niewłaściwe zakupy (niezaspokajające potrzeb życiowych - np. wino) ${ }^{21}$, zabawy z psem poprzez rzucanie patyka (a zdaniem funkcjonariusza policji należało się ograniczyć do spaceru) ${ }^{22}$, spacer z dzieckiem z niepełnosprawnością, dla którego wyjście było wówczas jedyną formą terapii (policjant nie uznawał tego za zaspokajanie potrzeb życiowych $)^{23}$, jazdę na rowerze - bez jednoznacznej informacji, co do celowości np. zakupów dla starszego członka rodziny ${ }^{24}$. W takich przypadkach wiele zależało od interpretacji i dobrej woli funkcjonariusza czy zdecyduje się na wystawienie mandatu, czy skieruje wniosek do sanepidu. Wysoki stopień uznaniowości decyzji powodował ich arbitralny charakter.

16 Ibidem.

17 Ustawa z dnia 20 maja 1971 r. Kodeks wykroczeń, Dz. U. 1971 Nr 12 poz. 114. ze zm.

18 Rozporządzenie Rady Ministrów z 31 marca 2020 roku...

19 Koronawirus: kara 30 tys. zł czy mandat 500 zl- od czego to zależy?, https:// www.rp.pl/Prawo-karne/304279917-Koronawirus-kara-30-tys-zl-czy-mandat-500-zl---od-czego-to-zalezy.html, (13.07.2020).

20 Ibidem.

21 Czym różni się kara $z$ sanepidu od mandatu policji za złamanie obostrzeń $w$ związku $z$ koronawirusem, https://prawo.gazetaprawna.pl/artykuly/1472715,kara-sanepid-mandat-policji-zlamanie-obostrzen-koronawirus-rpo.html, (13.07.2020).

22 Ibidem.

23 Ibidem.

24 Ibidem. 
Obywatel może „nie przyjąć” mandatu. Wówczas kieruje się wniosek o ukaranie do sądu, który rozstrzygnie, czy doszło do popełnienia wykroczenia. Od wyroku przysługuje odwołanie. Po jego uprawomocnieniu kara zostanie egzekwowana $\mathrm{z}$ konta oskarżonego. Prawomocny mandat karny podlega bowiem niezwłocznie uchyleniu, jeżeli grzywnę nałożono za czyn niebędący czynem zabronionym jako wykroczenie. Takie sprawy rozpatruje sąd rejonowy, który działa w miejscu, gdzie został nałożony mandat o ile dostał wniosek o uchylenie mandatu ${ }^{25}$.

Problem praktycznych kolizji z prawami człowieka nie wynika jedynie $\mathrm{z}$ braku klarowności i ostrości przepisów (obostrzeń) w wydanych rozporządzeniach i innych aktach prawnych, ale również ze zróżnicowanych interpretacji wykładni. Obywatel staje się ofiarą interpretacji, które godzą w jego podstawowe prawa i wolności, także w prawo do sądu.

Policja wymierza kary, składa wnioski do sądu. Opisane postępowanie występowało również przed okresem pandemii, jednakże wprowadzone obostrzenia sprawiają, że zakres działalności funkcjonariuszy zwiększył się. Zmienia to oblicze prawa i społeczeństwa. Funkcjonariusze zaczynają nadużywać kompetencji, poprzez wręczanie obywatelom mandatów, których wartość jest nieadekwatna do przewinienia ${ }^{26}$. Zaczyna to prowadzić do patologizacji władzy, zarówno na szczeblu lokalnym, poprzez działania funkcjonariuszy, jak i na szczeblu państwowym poprzez działania rządzących. We wszystkich tych działaniach można dostrzec kolizje ze standardami praw człowieka. Policja narusza osobiste prawa człowieka I generacji, takie jak: prawo do wolności osobistej, wolność słowa; wolność myśli, sumienia i wyznania; prawo do prywatności, a przede wszystkim równość wobec prawa. Nie każdy obywatel jest równy wobec prawa, a co więcej to nie sąd decyduje o tej równości a policja. Kwestia interpretacji i niejasności prawa pozwala na swobodę decyzyjną, co stwarza zagrożenie dla praw człowieka.

\section{Wybory prezydenckie w Polsce w sytuacji pandemii}

Wątpliwą i kontrowersyjną pozostawała kwestia organizacji wyborów prezydenckich w sytuacji pandemii. Działania rządu wskazywały na trwające przygotowania do wyborów korespondencyjnych (m.in. na podstawie ustawy o zwalczaniu epidemii COVID-19 wydrukowano pakiety wyborcze, pomijając zupełnie zapisy Kodeksu Wyborczego). Głosowanie w Sejmie dotyczące projektu ustanowienia trybu korespondencyjnego udziału w wyborach powszechnych na Prezydenta Rzeczypospolitej Polskiej zarzą-

25 Kara $30000 \mathrm{zł}$ czy mandat 500 zł? Od czego to zależy? Informator RPO, https://www.rpo.gov.pl/sites/default/files/Kara\%20administracyjna\%20czy\%20mandat\%20-\%20informator\%20RPO.pdf, (13.07.2020).

26 Wrócił PRL-owski „Pan Władza”? Policja traktuje obywateli jak niesforne dzieci, a rządzacy sa nietykalni, https://oko.press/wrocil-prl-owski-pan-wladza-polajanki-i-grozby-policja/, (12.05.2020). 
dzonych w 2020 r. jako jedynej formy głosowania, zostało wstępnie zaplanowane na dzień 7 maja trzy dni przed dniem, na który został wyznaczony termin przeprowadzenia wyborów prezydenckich ${ }^{27}$. Wprawdzie Marszałek Sejmu posiadał kompetencję do zmiany terminu wyborów prezydenckich, jednakże z tego prawa nie skorzystał. Taka sytuacja prowadzić może do zaniku poczucia stabilności prawa wśród społeczeństwa. Względem organów władzy publicznej, Konstytucja Rzeczypospolitej Polskiej w art. 7 określa granice i nakłada obowiązek działania na podstawie i $w$ granicach prawa ${ }^{28}$. Wobec przekraczania granic prawnych obywatele mogą czuć się zdezorientowani i coraz częściej tracą zaufanie wobec swoich przedstawicieli. Art. 4. Konstytucji RP wskazuje, że władza zwierzchnia w Rzeczypospolitej Polskiej należy do Narodu ${ }^{29}$. I dalej, w kolejnym paragrafie wskazuje, że Naród sprawuje władze przez swoich przedstawicieli lub bezpośrednio ${ }^{30}$. Zastosowanie korespondencyjnego modelu głosowania (już nie jako metody alternatywnej, z której korzysta mniejszość wyborców, ale jako metody powszechnej) niesie ze sobą szereg wyzwań organizacyjnych i technicznych, których realizacja wymaga odpowiedniego czasu. Rzecznik Praw Obywatelskich w opinii dla Senatu ws. głosowania korespondencyjnego na prezydenta $\mathrm{RP}^{31}$ podkreśla $\mathrm{z}$ kolei, że niewłaściwe funkcjonowanie takiej procedury wyborczej prowadzi do pozbawienia wyborcy możliwości skorzystania z czynnego prawa wyborczego. Kodeks Wyborczy wskazuje, że w przypadku zastosowania korespondencyjnej metody przeprowadzenia wyborów, pakiet wyborczy musi zawierać spersonalizowane dane każdego wyborcy, w tym także nr PESEL ${ }^{32}$. Fizyczne przygotowanie takich pakietów dla każdego z obywateli (uwzględniając także obywateli polskich mieszkających za granica) wymaga odpowiedniego czasu, tak więc wskazane dane osobowe musiałyby zostać przekazane operatorowi pocztowemu dużo wcześniej. Ustawa z dnia 16 kwietnia 2020 r. o szczególnych instrumentach wsparcia w związku z rozprzestrzenianiem się wirusa SARS-CoV-2 $2^{33}$, w art. 99 przekazuje operatorowi pocztowemu uprawnienie do otrzymania danych z rejestru PESEL. Pojawiają się jednak wątpliwości: czy gromadzenie, przetwarzanie i udostępnianie danych osobowych przez Pocztę Polską

27 Poselski projekt ustawy o szczególnych zasadach przeprowadzania wyborów powszechnych na Prezydenta Rzeczypospolitej Polskiej zarządzonych w 2020 r., Druk nr 328, http://www.sejm.gov.pl/sejm9.nsf/PrzebiegProc.xsp?nr=328, (13.09.2020).

28 Konstytucja..., art. 7.

29 Konstytucja..., art. 4.

30 Ibidem.

31 Opinia RPO dla Senatu ws. głosowania korespondencyjnego na prezydenta $R P z$ dnia 22 kwietnia 2020 roku, https://www.rpo.gov.pl/pl/content/koronawirus-rpo-do-senatu-ws-glosowania-korespondencyjnego, (10.07.2020)

32 Ustawa $z$ dnia 5 stycznia 2011 r. Kodeks wyborczy, Dz. U. 2011 Nr 21 poz. 112 ze zm., art. $53 \mathrm{~g}$.

33 Ustawa $z$ dnia 16 kwietnia 2020 r. o szczególnych instrumentach wsparcia w związku z rozprzestrzenianiem się wirusa SARS-CoV-2, Dz. U. 2020 poz. 695. 
S.A. nie ingeruje zbyt daleko w sferę prywatności obywatela i czy możliwy jest taki sposób głosowania w obliczu pandemii COVID-19, bez narażenia zdrowia i życia ludzkiego.

7 maja 2020 roku Państwowa Komisja Wyborcza wydała Komunikat $^{34}$, w którym oświadczyła, że wskutek ustawodawstwa związanego z epidemią wirusa SARS-CoV-2, została pozbawiona możliwości ustalenia wzoru karty do głosowania i zarządzenia druku kart. W związku z brakiem kart wyborczych nie mogły mieć zastosowania także inne przepisy Kodeksu Wyborczego związane z głosowaniem, dotyczące udostępnienia spisu wyborców czy ciszy wyborczej. 10 maja 2020 roku, pomimo zaplanowanych na ten dzień wyborów prezydenckich lokale wyborcze w całej Polsce pozostały zamknięte. Państwowa Komisja Wyborcza w Uchwale NR 129/2020 z dnia 10 maja 2020 roku $^{35}$ stwierdziła brak możliwości głosowania na kandydatów w wyborach na urząd Prezydenta Rzeczypospolitej Polskiej. Zgodnie z przepisami Kodeksu Wyborczego ${ }^{36}$, Marszałek Sejmu ogłosił nowy termin wyborów na 28 czerwca 2020 roku. Wybory prezydenckie odbyły się łącząc przy tym ze sobą dwie formy - formę alternatywną wyborów korespondencyjnych oraz formę tradycyjną, gdzie wyborcy mogli sami udać się do urn.

Polska regulacja prawna w sprawie wyborów prezydenckich $\mathrm{z}$ dnia 10 maja 2020 roku wywołała spore poruszenie w środowisku prawniczym. Krytyczne głosy pojawiały się jeszcze przed tą datą, nawołując jednocześnie do zmiany trybu wyborów i zastosowania legalnej procedury. Przywołując słowa byłego przewodniczącego Państwowej Komisji Wyborczej, Sędziego Wojciecha Hermelińskiego ${ }^{37}$ oczywistym było „że te wybory ze strony technicznej nie mogą się udać". Ponadto Sędzia wskazywał, że niezależnie od tego, czy byłyby to wybory kopertowe czy tradycyjne, naruszona zostanie zasada równości. Polskie wybory prezydenckie z 10 maja odbiły się echem nie tylko w Polsce ale także za granicą. Swoje stanowisko ws. projektu ustawy z dnia 6 kwietnia 2020 roku o szczególnych zasadach przeprowadzania wyborów powszechnych na Prezydenta Rzeczypospolitej Polskiej zarządzonych w 2020 roku przedstawiła także międzynarodowa organiza-

34 Komunikat Państwowej Komisji Wyborczej z dnia 7 maja 2020 roku, https://pkw.gov.pl/aktualnosci/wyjasnienia-stanowiska-komunikaty/komunikat-panstwowej-komisji-wyborczej-z-dnia-7-maja-2020roku, (10.07.2020).

35 Uchwała nr 129/2020 Państwowej Komisji Wyborczej z dnia 10 maja 2020 r. $w$ sprawie stwierdzenia braku możliwości głosowania na kandydatów w wyborach Prezydenta Rzeczypospolitej Polskiej, https://pkw.gov.pl/uploaded_files/1589173994_ uchwala-nr-129.pdf, (10.07.2020).

36 Ustawa z dnia 5 stycznia 2011 r. Kodeks wyborczy..., art. Dział V, Rozdział I.

37 J. Stępień: Istnieje pokusa wprowadzenia stanu wyjątkowego. To najczarniejszy scenariusz, trzeba się przed nim bronić, https://tvn24.pl/wybory-prezydenckie-2020/wybory-prezydenckie-2020-jerzy-stepien-o-najczarniejszym-scenariuszu-i-pokusie-wprowadzenia-stanu-wyjatkowego-4573527, (05.06.2020). 
cja Amnesty International ${ }^{38}$. We wskazówkach dla rządzących wskazała na konieczność uwzględnienia wolności zgromadzeń, prawa do przemieszczania się, wolności od strachu czy zasadę określoności i stabilności prawa. Organizacja zwróciła przede wszystkim uwagę na zagrożenie dla gwarancji praw człowieka w okresie poprzedzającym wybory oraz w czasie wyborów, jak również możliwość rzeczywistego wzięcia udziału w życiu publicznym i udziału w rządzeniu swoim krajem.

Stanowisko na temat wyborów prezydenckich niejednokrotnie wyraziła także prof. Ewa Łętowska podkreślając, że wraz z dniem 10 maja 2020 roku, Polska wkroczyła $w$ nowe stadium procesu pogarszania standardów praworządności $i^{39}$. W rozmowie z Rzecznikiem Praw Obywatelskich Adamem Bodnarem ${ }^{40}$, profesor zaznaczyła, że od daty wyborów trudno mówić o Polsce jako państwie prawa. Komentując aspekt przeprowadzenia wyborów prezydenckich podkreśla, że: tymczasem to, co się u nas stało w okresie marzec-czerwiec 2020: wielokrotne pospieszne i nieprzemyślane zmiany prawa wyborczego i zasad wyborów, $z$ naruszeniem ich równości, zwieńczone skandalem „odwołania” głosowania na kilka dni przed jego terminem, moca czysto politycznej decyzji liderów dwóch partii, nie przybranej w jakąkolwiek postać legalizacji prawnej, musi wpłynąć na obniżenie naszego indeksu demokracji w 2020 roku $^{41}$.

Zdanie $\mathrm{w}$ tej sprawie wypowiedział również Thomas Boserup, przewodniczący Specjalnej Misji Oceniającej Wybory Biura Instytucji Demokratycznych i Praw Człowieka OBWE (ODIHR). Podczas konferencji prasowej 13 lipca b.r. stwierdził, że kampania wyborcza nastawiona była na konfrontację $i$ by to $w$ niej wiele wzajemnego szkalowania się kandydatów na urzad Prezydenta $R P(\ldots)^{42}$. OBWE zaprezentowało negatywne stanowisko w stosunku do wyborów, podkreślając wrogość, groźby wobec mediów, retorykę nietolerancji oraz przypadki nadużyć zasobów państwowych. Ze stanowiskiem OBWE również łączy się kolejna sprawa mianowicie masowy

38 Stanowisko Amnesty International dotyczace projektu ustawy z dnia 6 kwietnia 2020 r. o szczególnych zasadach przeprowadzania wyborów powszechnych na Prezydenta Rzeczypospolitej Polskiej zarządzonych w 2020 r., https://amnesty.org. $\mathrm{pl} /$ stanowisko-amnesty-dotyczace-projektu-ustawy-o-szczegolnych-zasadach-przeprowadzania-wyborow-na-prezydenta-w-2020/, (10.07.2020).

39 E. Łętowska, P. Pacewicz, D. Sitnicka, Wywiad $z$ portalem OKO.press, https://oko.press/letowska-te-wybory-nie-beda-konstytucyjne-ja-bym-zostawila-szwindel-wladzy-w-jego-paskudnej-nagosci/, (10.07.2020).

40 A. Bodnar, E. Łętowska, Państwo prawa i prawa człowieka $w$ czasach koronawirusa prof. A. Bodnar (RPO) i prof. E. Łętowska, https://www.youtube.com/ watch?v=JRJbf0oEILQ\&feature=emb_err_woyt, (10.07.2020).

41 E. Łętowska, Nasza wadliwa, folwarczna demokracja. Gorzki esej prof. Ewy Łętowskiej, https://oko.press/nasza-wadliwa-folwarczna-demokracja-gorzki-esej-prof-ewy-letowskiej/, (10.07.2020).

42 Stanowisko $w$ sprawie wstępnych wniosków i ustaleń z 12 lipca 2020 r., Misja specjalna oceny wyborów ODIHR, https://www.osce.org/files/f/documents/a/f/457213_1.pdf, (25.07.2020). 
sprzeciw sędziów wobec wyborów. Sędziowie z Piotrkowa Trybunalskiego wystosowali list do OBWE, przesłany 29 kwietnia $2020 \mathrm{roku}^{43}$. Sędziowie domagali się w nim, aby organizacja objęła wybory prezydenckie monitoringiem i wysłała na nich swoich obserwatorów. Rzecznik dyscyplinarny działający przy Sądzie Okręgowym w Piotrkowie Trybunalskim wszczął postępowanie wyjaśniającego wobec 15 sędziów z sądów rejonowych, gdzie zażądał wyjaśnień w sprawie listu ${ }^{44}$.

Obserwując sytuację w kraju należy zadać sobie pytanie: gdzie jest granica pomiędzy ograniczaniem praw obywatelskich $\mathrm{w}$ związku z pandemią COVID-19 a realizacją konstytucyjnych praw i wolności obywatelskich? Amnesty International publikując coroczny raport na temat przestrzegania praw człowieka w Europie i Azji Centralnej podjęła także temat praworządności w dobie pandemii COVID-19. Z krytyką Stowarzyszenia spotkały się działania władz Turcji, Węgier a także Polski. Zarzucono polskim władzom $\mathrm{m}$.in. wykorzystanie pandemii koronawirusa do debat o zaostrzeniu prawa aborcyjnego ${ }^{45}$. Draginja Nadaždin, dyrektor Amnesty Innternational Polska, uważa, że pandemia i wybory przyczyniły się do pogłębienia kryzysu praworządności trwającego w Polsce od lat, a zaistniała sytuacja wydaje się być wykorzystywana jako „przykrywka” dla rządzących w realizacji własnych celów politycznych ${ }^{46}$.

\section{Skutki prawne COVID-19 w Europie}

Podstawowym mechanizmem wykorzystywanym przez państwa Unii Europejskiej (i inne) było zamknięcie granic, bądź tymczasowe ograniczenie ruchu - tylko do przejazdów samochodów dostawczych, tirów, czy wobec obywateli powracających do kraju. Obywatel, który wrócił do kraju był zmuszony do poddania się wspomnianemu obowiązkowi 14-dniowej kwarantanny ${ }^{47}$. Kwestia ta godziła $\mathrm{w}$ prawa człowieka, a przede wszyst-

43 Pismo sędziów polskich do OBWE w sprawie wyborów prezydenckich, https:// forumfws.eu/glos-w-sprawie/sedziowie-obwe/, (13.09.2020).

44 Patrycja Rojek-Socha, Sędziowie napisali do OBWE - rzecznik dyscyplinarny chce wziąć "pod lupę" ponad 1000osób, https://www.prawo.pl/prawnicy-sady/sedziowie-napisali-do-obwe-rzecznik-dyscyplinarny-chce,502486.html, (13.09.2020).

45 Zdalny Sejm, zdalny protest. Co zakłada projekt Kai Godek?, https:// www.rp.pl/Spor-o-aborcje/200419658-Zdalny-Sejm-zdalny-protest-Co-zaklada-projekt-Kai-Godek.html,Obywatelski projekt ustawy o zmianie ustawy $z$ dnia 7 stycznia 1993 r. o planowaniu rodziny, ochronie płodu ludzkiego i warunkach dopuszczalności przerywania ciąży, Druk nr 2146 (13.09.2020).

46 Stanowisko Amnesty International dotyczące projektu ustawy $z$ dnia 6 kwietnia $2020 \mathrm{r}$.

47 Koronawirus. Kłopoty ludzi z kwarantanna, https://www.rpo.gov.pl/pl/content/koronawirus-nieprawidlowosci-z-kwarantanna-sygnalizowane-przez-obywateli-rpo, (01.09.2020). 
kim w prawo do wolności i prawo wyboru. Niewykonanie tego zalecenia mogło skutkować w danym państwie europejskim wysoką sankcją.

Z uwagi na pandemię COVID-19 niektóre państwa zdecydowały się na wprowadzenie stanu wyjątkowego. Jednym $\mathrm{z}$ takich państw były Węgry, w których cała władza obecnie spoczywa w rękach premiera Viktora Orbana $^{48}$. Oponenci orbanowskiego sposobu rządzenia twierdzą, że jest to zbliżenie się do prowadzenia polityki w sposób wschodni, gdzie Orban celowo wprowadza stan wyjątkowy, aby przejmować coraz większy zakres władzy, dążąc do przekształcenia Węgier w państwo o charakterze autory$\operatorname{tarnym}^{49}$. W takiej sytuacji prawa człowieka a przede wszystkim jego podstawowe wolności zostają zawieszone na wskutek ,,wyższego dobra”, którym jest los państwa, a w sytuacji pandemii zdrowie obywateli. Ponadto Węgry chciały wprowadzić rygorystyczne sankcje za rozpowszechnianie fałszywych informacji na temat koronawirusa ${ }^{50}$. Najsurowszym środkiem jest kara pozbawienia wolności do lat $5^{51}$. Wywołało to spore oburzenie w mass mediach, zważywszy na kwestię wolności słowa. Wolność słowa i możliwość wyrażania swoich poglądów należy do praw człowieka I generacji, które powinny być bardzo ostrożnie ograniczane, w szczególności jeśli chodzi o sprawy związane z życiem i zdrowiem ludzkim, które stanowią wypowiedź w interesie publicznym. Węgry izolują się i zamykają granicę dla obcokrajowców nie mieszkających na stałe w danym państwie.

\subsection{Austria}

Austria pomimo stosunkowo dużego wskaźnika zachorowań w stosunku do liczby ludności kraju nie wprowadziła stanu wyjątkowego. Obecny kanclerz Sebastian Kurz przedłużył jednak środki nadzwyczajne przyjęte $\mathrm{w}$ związku z koronawirusem. Najnowszymi z nich są obostrzenia dotyczące zamknięcia całej branży hotelarskiej na czas do 13 kwietnia 2020 roku włącznie, nakaz noszenia maseczek ochronnych w miejscach publicznych, możliwość wyjścia $\mathrm{z}$ domu jedynie w celach zawodowych bądź w celu zrobienia zakupów oraz spaceru $\mathrm{z}$ psem ${ }^{52}$. Pomimo tych restrykcji rząd au-

48 Viktor Orban przejmuje petnię władzy, parlament został zawieszony, https://wiadomosci.gazeta.pl/wiadomosci/7,173952,25834974,wegry-viktor-orban-przejmuje-pelnie-wladzy-parlament-zostal.html, (01.04.2020).

49 Ibidem.

50 Koronawirus. Wegry: rzą chce karać za fake newsy, https://wiadomosci. onet.pl/swiat/koronawirus-wegry-rzad-chce-karac-za-fake-newsy/4ly7x7s, (01.04.2020).

51 Ibidem.

52 Bundesgesetzblatt für die Republik Österreich - COVID - 19 Gesetz, NR: GP XXVII IA 483/A AB 120 S. 27. BR: 10293 AB 10300 S. 906. 
striacki wprowadził obostrzenia w taki sposób, aby jak najmniej naruszały one swobody obywatelskie oraz wolności zagwarantowane w Europejskiej Konwencji Praw Człowieka ${ }^{53}$. Od początku maja 2020 roku gospodarka $\mathrm{w}$ Austrii ustabilizowała się ${ }^{54}$. Austria jako jedno z pierwszych państw członkowskich UE złagodziła pandemiczne obostrzenia. Otwarto restauracje i miejsca użytku publicznego. Kwestią sporną natomiast stały się uczelnie oraz szkoły. Nauczanie nadal pozostało na poziomie zdalnym i trudno przewidzieć czy i kiedy się to zmieni. Pomimo zachorowań obywateli Austrii na COVID-19, państwo nie nakładało specjalnych obostrzeń, a co więcej było jednym z pierwszych, które zniosło kontrole graniczne, przywracając możliwość swobodnego podróżowania wewnątrz, jak i poza granice kraju. Ponadto jako pierwsze również zniosło kwestie odbywania kwarantanny po przyjeździe ${ }^{55}$.

\subsection{Włochy}

Największe skupisko ludzi zarażonych w krajach Unii Europejskiej znajduje się we Włoszech ${ }^{56}$. Kraj ten wprowadził podobne obostrzenia, jakie wprowadzono w Polsce. Opuszczenie miejsca zamieszkania było możliwe jedynie w celu załatwienia spraw bieżącej potrzeby, bądź w celach zawodowych - jak praca, czy wolontariat. Jednym z zakazów wprowadzonych zaraz po wybuchu epidemii był zakaz kąpieli w morzu. Wprowadzono również obostrzenia dotyczące poruszania się, czy też zawieszenie spektakli filmowych i telewizyjnych. W połowie marca br. zostały zamknięte bary oraz restauracje (nie licząc restauracji na lotniskach oraz w szpitalach), jednakże takie punkty jak apteki, sklepy spożywcze, czy też galerie handlowe nie zostały zamknięte $^{57}$. Co więcej, premier Włoch Giuseppe Conte stwierdził, ,,ze pomimo dużej skali zakażenia wirusem COVID-19 nie zamierza wprowadzać drakońskich kroków ze względu na troskę o gospodarkę rynku włoskiego" ${ }^{\text {"58 }}$. Włoski rząd nie

53 Europejska Konwencja Praw Człowieka z 3 września 1953 roku.

54 Gospodarczy restart. Najpierw Austria, później Niemcy i Włosi, https://biznes.interia.pl/gospodarka/news-gospodarczy-restart-najpierw-austria-pozniej-niemcy-i-wlosi,nId,4426636, (15.05.2020).

55 Austria:16 czerwca zniesienie ograniczeń dla przyjezdnych z Polski, https:// www.gazetaprawna.pl/artykuly/1482598, austria-polska-zniesienie-ograniczen. html, (10.08.2020).

56 Koronawirus w Europie: najwięcej przypadków we Włoszech, Francji, Niemczech $i$ Hiszpanii, https://forsal.pl/artykuly/1458690,koronawirus-w-europie-najwiecej-przypadkow-we-wloszech-francji-niemczech-i-hiszpanii.html, (11.03.2020).

57 Drastyczne środki włoskiego rząu. Lombardia odcięta od świata, https:// www.forbes.pl/wiadomosci/wlochy-zaostrzaja-walke-z-koronawirusem/cb5drtn, (20.03.2020).

58 Włochy: Rząd zaostrza przepisy o walce $z$ epidemiq ale unika drakońskich kroków, https://www.wnp.pl/rynki-zagraniczne/wlochy-rzad-zaostrza-przepisy-o-walce-z-epidemia-ale-unika-drakonskich-krokow,381017.html, (22.03.2020). 
skrócił godzin pracy supermarketów i galerii handlowych w weekendy ${ }^{59}$. Polityka bezpieczeństwa względem COVID-19 we Włoszech ma zarówno wielu zwolenników jak i przeciwników wśród społeczeństwa i osób publicznych. Niektórzy mówią, że działanie to nie jest rozsądne, bo powoduje dalsze rozprzestrzenianie się epidemii. Z kolei zwolennicy twierdzą, iż zostały podjęte wystarczające kroki, aby ochronić społeczeństwo przed dalszą inwazją koronawirusa galerie handlowe czy też sklepy spożywcze muszą funkcjonować, aby dostarczać przedmioty pierwszej potrzeby.

Włochy są krajem, w którym został wprowadzony stan wyjątkowy. $\mathrm{Z}$ jednej strony wprowadzone restrykcje mają chronić ludzi przed możliwym zachorowaniem, $\mathrm{z}$ drugiej strony zaś ingerują w prawo do wolności.

\subsection{Hiszpania}

Państwem europejskim, w którym również zanotowano wysoki poziom zachorowań na wirusa COVID-19 jest Hiszpania. W Hiszpanii w trosce o bezpieczeństwo obywateli, jak i również dla regulacji prawnej podjętych działań został wprowadzony stan wyjątkowy ${ }^{60}$. Niestety kroki podjęte przez rząd hiszpański także stanowiły ingerencję $\mathrm{w}$ prawa człowieka (zakaz wychodzenia $\mathrm{z}$ dziećmi na spacery czy też wyjście w dwie osoby do parku). Wyjątkiem zezwalającym na opuszczenie domostwa jest wyjście z psem na spacer $^{61}$. Hiszpania zamknęła wszystkie przedszkola i szkoły, aż do odwołania $^{62}$. Interesującym obostrzeniem nałożonym przez hiszpański rząd jest zakaz podróży samochodem przez więcej niż jedną osobę ${ }^{63}$.

\section{Podsumowanie}

Czy byliśmy gotowi na pandemię COVID-19? Na pewno nie, pomimo ostrzeżeń świata nauki o występowaniu takiego prawdopodobieństwa. Należy teraz postawić sobie pytanie, jak wybrnąć z sytuacji i jak najszybciej podjąć ku temu kroki? Dlatego też analiza zastanej sytuacji ma bardzo istotne znaczenie. Przede wszystkim trzeba zasięgnąć informacji, stworzyć skuteczne prawo i obserwować reakcję społeczeństwa. Jednocześnie konieczna jest analiza sytuacji w innych krajach dotkniętych COVID-19 i wy-

59 Ibidem.

60 W Hiszpanii ogłoszono stan wyjątkowy, https://www.rp.pl/Koronawirus-2019-nCoV/200319538-W-Hiszpanii-ogloszono-stan-wyjatkowy.html, (20.03.2020).

61 Koronawirus. Na spacer tylko z psem, i to krótki, https://warszawa.wyborcza. pl/warszawa/7,54420,25810971,koronawirus-na-spacer-tylko-z-psem-i-to-krotki. html, (30.03.2020).

62 W Hiszpanii ogłoszono stan wyjątkowy, https://www.rp.pl/Koronawirus-2019-nCoV/200319538-W-Hiszpanii-ogloszono-stan-wyjatkowy.html, (20.03.2020).

63 Ibidem. 
ciągnięcie wniosków, które działania były skuteczne a co można było zrobić lepiej. Opis początkowej sytuacji pandemii ma na celu ocenę skuteczności podjętych kroków, jak również wyciągnięcie wniosków na przyszłość. Skutki Covid-19 widoczne są na płaszczyźnie prawnej, jak i społecznej. Niekiedy wirus COVID-19 porównywany jest do dżumy ${ }^{64}$, czyli czarnej śmierci, która siała spustoszenie w wieku XVII. Wskaźnik zachorowań na dżumę oraz wskaźnik zgonów w tamtym okresie przypomina statystyki związane $\mathrm{z}$ współczesnym koronawirusem. Entuzjaści widzą w nim jednak pozytywy, takie jak np. zmniejszenie zanieczyszczenia powietrza i smogu ${ }^{65}$. Sceptycy natomiast przystają przy negatywnym wpływie koronawirusa nie tylko na prawo i społeczeństwo, ale przede wszystkim na życie ludzi na całym świecie. Ludzkość jest podzielona - na osoby, które widzą w obostrzeniach szanse na zmniejszenie liczby zachorowań, oraz na osoby, w które bezpośrednio i pośrednio uderza nowe prawo, łamiąc przy tym wszelkie konwencje i deklaracje. Państwo i prawo skupiają w sobie obostrzenia, które mają zapewnić społeczeństwu bezpieczeństwo. Problematyczna jednak okazuje się granica pomiędzy dobrem ogółu a prawami i wolnościami gwarantowanymi każdemu człowiekowi. Pytanie na ile można w nie ingerować, wprowadzając kolejne restrykcje pozostaje wciąż otwarte.

\section{Bibliografia}

\section{Wykaz aktów prawnych}

Bundesgesetzblatt für die Republik Österreich - COVID - 19 Gesetz, NR: GP XXVII IA 483/A AB 120 s. 27. BR: 10293 AB 10300 s. 906.

Europejska Konwencja Praw człowieka z dnia 3 września 1953 r.

Konstytucja Rzeczypospolitej Polskiej z dnia 2 kwietnia 1997 r., Dz.U. Nr 78, poz. 483 ze zm.

Powszechna Deklaracja Praw Człowieka, Paryż, 10 grudnia 1948 roku.

Rozporządzenie Ministra Zdrowia z dnia 20 marca 2020 roku w sprawie ogłoszenia na obszarze Rzeczypospolitej Polskiej stanu epidemii, Dz.U.2020.491.

Rozporządzenie Rady Ministrów z 31 marca 2020 roku sprawie ustanowienia określonych ograniczeń, nakazów i zakazów w związku z wystąpieniem stanu epidemii, Dz.U. 2020 poz. 566.

Rozporządzenie Rady Ministrów z dnia 15 kwietnia 2020 r. zmieniające rozporządzenie w sprawie ustanowienia określonych ograniczeń, nakazów i zakazów w związku z wystąpieniem stanu epidemii, Dz. U. 2020 poz. 673.

64 Współczesna dżuma niszczy nasze zaufanie i nasze prawa, https://podhale24.pl/aktualnosci/artykul/69256/Wspolczesna_dzuma_niszczy_nasze_zaufanie_i_nasze_prawa.html, (20.04.2020).

65 Epidemia koronawirusa oczyściła powietrze. Badania to potwierdzają, https://portalkomunalny.pl/epidemia-koronawirusa-oczyscila-powietrze-badania-to-potwierdzaja-402339/, (04.04.2020). 
Ustawa z dnia 14 czerwca 1960 r. Kodeks postępowania administracyjnego, Dz. U. $1960 \mathrm{Nr} 30$ poz. 168 ze zm.

Ustawa z dnia 16 kwietnia 2020 r. o szczególnych instrumentach wsparcia w związku z rozprzestrzenianiem się wirusa SARS-CoV-2, Dz. U. 2020 poz. 695.

Ustawa z dnia 20 maja 1971 r. Kodeks wykroczeń, Dz. U. $1971 \mathrm{Nr} 12$ poz. 114. ze zm.

Ustawa z dnia 24 sierpnia 2001 r. Kodeks postępowania w sprawach o wykroczenia, Dz. U. 2001 Nr 106 poz. 1148 ze zm.

Ustawa z dnia 31 marca 2020 r. o zmianie niektórych ustaw w zakresie systemu ochrony zdrowia związanych z zapobieganiem, przeciwdziałaniem i zwalczaniem COVID-19, Dz. U. 2020 poz. 567.

Ustawa z dnia 5 stycznia 2011 r. Kodeks wyborczy, Dz. U. 2011 Nr 21 poz. 112 ze $\mathrm{zm}$.

\section{Netografia}

Bodnar A., Łętowska E., Państwo prawa i prawa człowieka w czasach koronawirusa prof. A. Bodnar (RPO) i prof. E. Łętowska, https://www.youtube.com/ watch?v=JRJbf0oEILQ\&feature=emb_err_woyt, (10.07.2020).

Czym się różni kara $z$ sanepidu od mandatu policji za złamanie obostrzeń. RPO Wyjaśnia”, https://prawo.gazetaprawna.pl/artykuly/1472715,kara-sanepid-mandat-policji-zlamanie-obostrzen-koronawirus-rpo.html?fbclid=IwAR3pjaHomBBoBm1gl1nppsEjy1B7DclPpPtWZcwS9mqmvdZou03nbPbFUdw, (01.05.2020).

Jałoszewski M., Masowy sprzeciw sędziów: kilkuset napisało na siebie donos, bo nie boja się ludzi Ziobry, https://oko.press/masowy-sprzeciw-sedziow-kilkuset-napisalo-na-siebiedonos/?utm_medium=Social\&utm_source=Twitter\&fbclid=IwAR35B0I5Kp9IDgmZ3qlevMjh7jI53zjv9Jxw5guzdmKlPftqrKiKPJ1YmP4, (29.07.2020).

Kara 30000 zł czy mandat 500 zł? Od czego to zależy? Informator RPO, https:// www.rpo.gov.pl/sites/default/files/Kara\%20administracyjna\%20czy\%20mandat\%20-\%20informator\%20RPO.pdf, (13.07.2020).

Komunikat Państwowej Komisji Wyborczej z dnia 7 maja 2020 roku, https://pkw. gov.pl/aktualnosci/wyjasnienia-stanowiska-komunikaty/komunikat-panstwowej-komisji-wyborczej-z-dnia-7-maja-2020-roku, (10.07.2020).

Koronawirus. Wegry: rzą chce karać za fake newsy, https://wiadomosci.onet.pl/swiat/koronawirus-wegry-rzad-chce-karac-za-fake-newsy/4ly7x7s, (01.04.2020).

Łętowska E., Nasza wadliwa, folwarczna demokracja. Gorzki esej prof. Ewy Łętowskiej, https://oko.press/nasza-wadliwa-folwarczna-demokracja-gorzki-esej-prof-ewy-letowskiej/, (10.07.2020).

Łętowska E., Pacewicz P., Sitnicka D., Wywiad z portalem OKO.press, https://oko. press/letowska-te-wybory-nie-beda-konstytucyjne-ja-bym-zostawila-szwindel-wladzy-w-jego-paskudnej-nagosci/, (10.07.2020).

Oficjalna strona internetowa Ministerstwa Zdrowia, https://www.gov.pl/web/zdrowie, (13.07.2020). 
Opinia RPO dla Senatu ws. głosowania korespondencyjnego na prezydenta RP z dnia 22 kwietnia 2020 r., https://www.rpo.gov.pl/pl/content/koronawirus-rpo-do-senatu-ws-glosowania-korespondencyjnego, (10.07.2020).

Poselski projekt ustawy o szczególnych zasadach przeprowadzania wyborów powszechnych na Prezydenta Rzeczypospolitej Polskiej zarządzonych w 2020 r., Druk nr 328, http://www.sejm.gov.pl/sejm9.nsf/PrzebiegProc.xsp?nr=328, (13.09.2020).

Rojek-Socha P., Sędziowie napisali do OBWE - rzecznik dyscyplinarny chce wziać "pod lupę" ponad 1000 osób, https://www.prawo.pl/prawnicy-sady/sedziowie-napisali-do-obwe-rzecznik-dyscyplinarny-chce,502486.html, (13.09.2020).

Stanowisko Amnesty International dotyczace projektu ustawy $z$ dnia 6 kwietnia 2020 r. o szczególnych zasadach przeprowadzania wyborów powszechnych na Prezydenta Rzeczypospolitej Polskiej zarządzonych w 2020 r., https://amnesty.org.pl/ stanowisko-amnesty-dotyczace-projektu-ustawy-o-szczegolnych-zasadach-przeprowadzania-wyborow-na-prezydenta-w-2020/, (10.07.2020).

Stanowisko OBWE (ODIHR) w sprawie wstępnych wniosków i ustaleń, Misja specjalna oceny wyborów ODIHR, Rzeczpospolita Polska - Wybory prezydenckie, druga tura, 12 lipca 2020 r. , https://www.facebook.com/groups/CourseraConnections/?launch_popover=membership_questionnaire , (25.07.2020).

Stępień J.: Istnieje pokusa wprowadzenia stanu wyjątkowego. To najczarniejszy scenariusz, trzeba się przed nim bronić., https://tvn24.pl/wybory-prezydenckie-2020/wybory-prezydenckie-2020-jerzy-stepien-o-najczarniejszym-scenariuszu-i-pokusie-wprowadzenia-stanu-wyjatkowego-4573527, (05.06.2020).

Uchwała nr 129/2020 Państwowej Komisji Wyborczej z dnia 10 maja 2020 r. w sprawie stwierdzenia braku możliwości głosowania na kandydatów w wyborach Prezydenta Rzeczypospolitej Polskiej, https://pkw.gov.pl/uploaded_files/1589173994_uchwala-nr-129.pdf, (10.07.2020).

Wegry. Viktor Orban przejmuje petnię władzy, parlament został zawieszony, https:// wiadomosci.gazeta.pl/wiadomosci/7,173952,25834974, wegry-viktor-orban-przejmuje-pelnie-wladzy-parlament-zostal.html, (01.04.2020).

Zdalny Sejm, zdalny protest. Co zakłada projekt Kai Godek?, https://www.rp.pl/ Spor-o-aborcje/200419658-Zdalny-Sejm-zdalny-protest-Co-zaklada-projekt-Kai-Godek.html, (13.09.2020).

Wpływ Covid-19 na społeczeństwo i prawo. Wybrane aspekty polskich i europejskich regulacji prawnych

Abstrakt

W artykule zawarto najważniejsze aspekty dotyczące wpływu wirusa Covid-19 na europejskie społeczeństwo oraz prawo. Zwrócono uwagę na kwestie związane z wprowadzonymi obostrzeniami ukazując dodatkowo różnice pomiędzy innymi krajami Unii Europejskiej. Ponadto przedstawiono takie aspekty jak: sankcje za nieprzestrzeganie prawa w Polsce, wybory prezydenckie 2020, czy też sytuację prawną obowiązującą w takich krajach jak Węgry, Austria, Włochy czy też Hiszpania. Zakres czasowy przeprowadzonej analizy obejmuje okres wprowadzania obostrzeń w państwach. W artykule ujęto stanowiska znanych osób, jak i organizacji, co do sposobu wprowadzenia i charakteru restrykcji i obostrzeń. Celem artykułu jest przedstawienie negatywnego wpływu wirusa Covid-19 oraz opis sposobu reagowania władz poszczególnych państw 
na zaistniałą sytuację. W artykule przywołano przykłady stosowania prawa, stanowiące konsekwencję wprowadzanych zmian w państwie oraz zwiększenia kompetencji aparatu policyjnego. Wirus Covid-19, potocznie nazywany „koronawirusem” znacząco osłabił gospodarki krajów europejskich, jak również doprowadził do bagatelizacji praw ustanowionych. Jak w Polsce wyglądała sytuacja od marca 2020 oraz czy wprowadzone rozporządzenia jak i również ustawy były w pełni kompatybilne z obowiązującym prawem i zasadami? Odpowiedzi między innymi na te pytania Autorzy starają się udzielić w niniejszym artykule.

Słowa kluczowe: COVID-19, obostrzenia, sankcje, wybory prezydenckie 2020, sytuacja prawna

\title{
The Impact of Covid-19 on Society and Law: Selected Aspects of Polish and European Legislation
}

\begin{abstract}
In our research approach, we have focused on the negative influence of SARS-Cov-2on European society and legislation. This topic concerns each one of us. The pandemic has become an enormous challenge for the legislator. We look at howrecentregulationshasbeenaffectingfunctioningofsocietyorrespectinghuman rights, concluding that they were at risk with no sign of improvement. We discuss some key issues related to human rights and Polish legislation onCOVID-19, i.e. the Ordinance of the Minister of Health of 20 March 2020 or Regulations of the Council of Ministers of 31 March 2020. Those acts, for instance, included prohibitions on personal movement, with the exception of for the purpose of performing work and business tasks as well as satisfying necessary daily need, which was a major limitation of freedom. Closing most work places, in turn, violated second-generation human rights. We also mention the financial penalties and their unsuitability given other punishments for unlawful acts. In addition, we describe two ways of receiving fines, classified and characterised based on competent decision-making authorities. The new procedures entail extended prerogatives granted to the police. As result, the problem appears of interpretation of human rights as well as possible infringements of fundamental human rights. Our article contains a short description of difficulties related to the presidential election in the context of the coronavirus pandemic. To ensure a comprehensive analysis of therese arch problem, we have compared Polish legislation with legal solutions adopted by other counties.
\end{abstract}

Keywords: COVID-19, restrictions, sanctions, presidential election 2020, legal situation 